\title{
The Installation of a Multiport Ground-Water Sampling System in the 300 Area
}

T. J. Gilmore

June 1989

Prepared for the U.S. Department of Energy under Contract DE-AC06-76RLO 1830

Pacific Northwest Laboratory Operated for the U.S. Department of Energy by Battelle Memorial Institute 


\title{
DISCLAIMER
}

This program was prepared as an account of work sponsored by an agency of the United States Government. Neither the United States Government nor any agency thereof, nor Battelle Memorial Institute, nor any of their employees, makes any warranty, express or implied, or assumes any legal liabltity or responsibility for the accuracy, completeness, or usefulness of any information, apparatus, product, or process disclosed, or represents that tis use would not infinge privately owned hghts. Reference herein to any specific commerical product, process, or service by trade name, trademark, manufacturer, or otherwise, does not necessarily constitute or imply its endorsement, recommendation, or favoring by the United States Government or any agency thereof, or Battelle Memorial Institute. The views and opinions of authors expressed herein do not necessarily state or reflect those of the United States Government or any agency thereof.

\section{PACIFIC NORTHWEST LABORATORY operated by \\ BATTELLE MEMORIAL INSTITUTE for the \\ UNITED STATES DEPARTMENT OF ENERGY under Contract DE-AC06-76RLO 1830}

\author{
Printed in the United States of America \\ Available from \\ National Technical Information Service \\ United States Department of Commerce \\ 5285 Port Royal Road \\ Springfield, Virginia 22161 \\ NTIS Price Codes \\ Microfiche A01 \\ Printed Copy
}

$\begin{array}{lc}\text { Pages } & \begin{array}{c}\text { Price } \\ \text { Codes } \\ 001-025\end{array} \\ 026-050 & \text { A02 } \\ 051-075 & \text { A03 } \\ 076-100 & \text { A04 } \\ 107-125 & \text { A05 } \\ 126-150 & \text { A06 } \\ 151-175 & \text { A07 } \\ 176-200 & \text { A06 } \\ 201-225 & \text { A09 } \\ 226-250 & \text { A10 } \\ 251-275 & \text { A11 } \\ 276-300 & \text { A12 } \\ & \text { A13 }\end{array}$


PNL -6910

UC- 11,41

THE INSTALLATION OF A MULTIPORT GROUND-WATER SAMPLING SYSTEM IN THE 300 AREA

T. J. Gi7more

June 1989

Prepared for

the U.S. Department of Energy

under Contract DE-AC06-76RLO 1830

Pacific Northwest Laboratory

Richland, Washington 99352 


\section{SUMMARY}

In 1988, the Pacific Northwest Laboratory installed a multiport groundwater sampling system in well 399-1-20, drilled north of the 300 Area on the Hanford Site in southeastern Washington State. The purpose of installing the multiport system is to evaluate methods of determining the vertical distribution of contaminants and hydraulic heads in ground water.

We11 399-1-20 is adjacent to a cluster of four Resource Conservation and Recovery Act (RCRA) ground-water monitoring wells. This proximity makes it possible to compare sampling intervals and head measurements between the multiport system and the RCRA monitoring wells. Drilling and installation of the multiport system took 42 working days. Six sampling ports were installed in the upper unconfined aquifer at depths of approximately 120 , $103,86,74,56$, and 44 feet. The locations of the sampling ports were determined by the hydrogeology of the area and the screened intervals of adjacent ground-water monitoring wells.

The system was installed by backfilling sand around the sampling ports and isolating the ports with bentonite seals. The method proved adequate. For future installations, however, development and evaluation of an alternative method is recommended. In the alternative method suggested, the multiport system would be placed inside a cased and screened well, using packers to isolate the sampling zones. 



\section{CONTENTS}

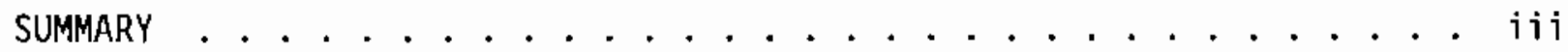

INTRODUCTION . . . . . . . . . . . . . . . . . . . . . 1

CONCLUSIONS AND RECOMMENDATIONS . . . . . . . . . . . . . . . . . 5

CONCLUSIONS . . . . . . . . . . . . . . . . . . 5

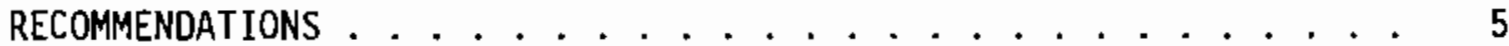

GEOLOGY AND GEOPHYSICAL LOGGING . . . . . . . . . . . . . . . 9

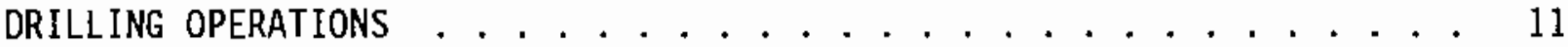

COMPLETION AND INSTALLATION . . . . . . . . . . . . . . . . . 13

FILTER PACK AND ANNULAR SEAL MATERIALS . . . . . . . . . . . 15

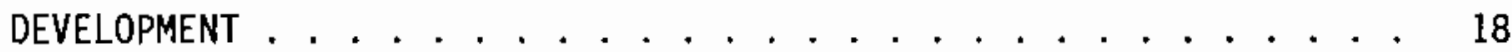

REFERENCES . . . . . . . . . . . . . . . . . . . . . . 21

APPENDIX - WELL LOGS ANO OTHER RECORDS ................... . . . I 


\section{FIGURES}

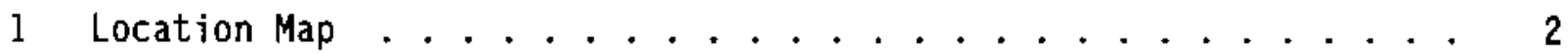

2300 Area Location Map ................ 3

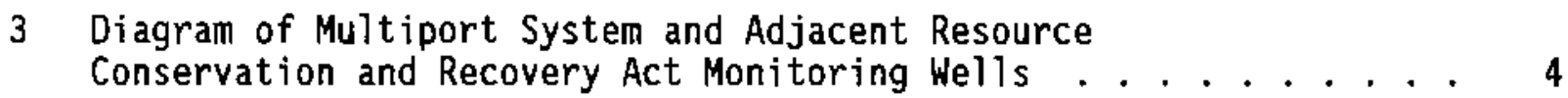

4 Installation of Multiport System in a Cased and $2 . \ldots 6$

5 Construction Progress Curve .............. 11

6 Completion Arrangement at the Well Head ............ 14

7 Multiport Monitoring Zone Configuration .......... 16

8 Pressure Transducer Readings . . . . . . . . . . . . . 17

\section{$\underline{\text { TABLES }}$}

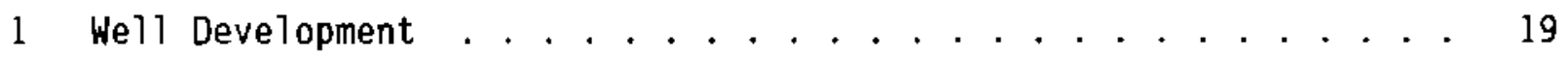




\section{INTRODUCTION}

A Westbay multiport ground-water sampling system was installed in a borehole on the Hanford Site as part of Pacific Northwest Laboratory's (PNL's) Hanford Site-Wide Ground-Water Monitoring Project. Installation of the multiport system is part of a program to evaluate methods for determining the vertical distribution of contaminants and hydraulic heads in ground water. Borehole 399-1-20 was drilled for the multiport system in November 1988 by Onwego Drilling Company, Richland, Washington, under subcontract to PNL. PNL furnished contract management and supervised the drilling and installation of the multiport system. Geologic data were gathered by PNL personnel. Under contract to PNL, Westbay Instruments Ltd. provided initia1 consultation on the assembly and installation of the system.

Borehole 399-1-20 is located on the Hanford Site in southeastern Washington State (Figures 1 and 2). Hanford Plant coordinates for the borehole are N55,795.2 E15,707.5. Ground surface elevation is 383.16 feet above mean sea level and the top of the casing is at 385.46 feet above mean sea leve]. The multiport system was installed to the north of the 300 Area, immediately adjacent to a cluster of four Resource Conservation and Recovery Act (RCRA) ground-water monitoring wells completed at various depths in the aquifers within the suprabasalt sediments (Figure 3 ). This location makes it possible to compare sampling intervals between the multiport system and the RCRA monitoring wells.

This report summarizes the drilling and installation of the multiport system in borehole 399-1-20. 


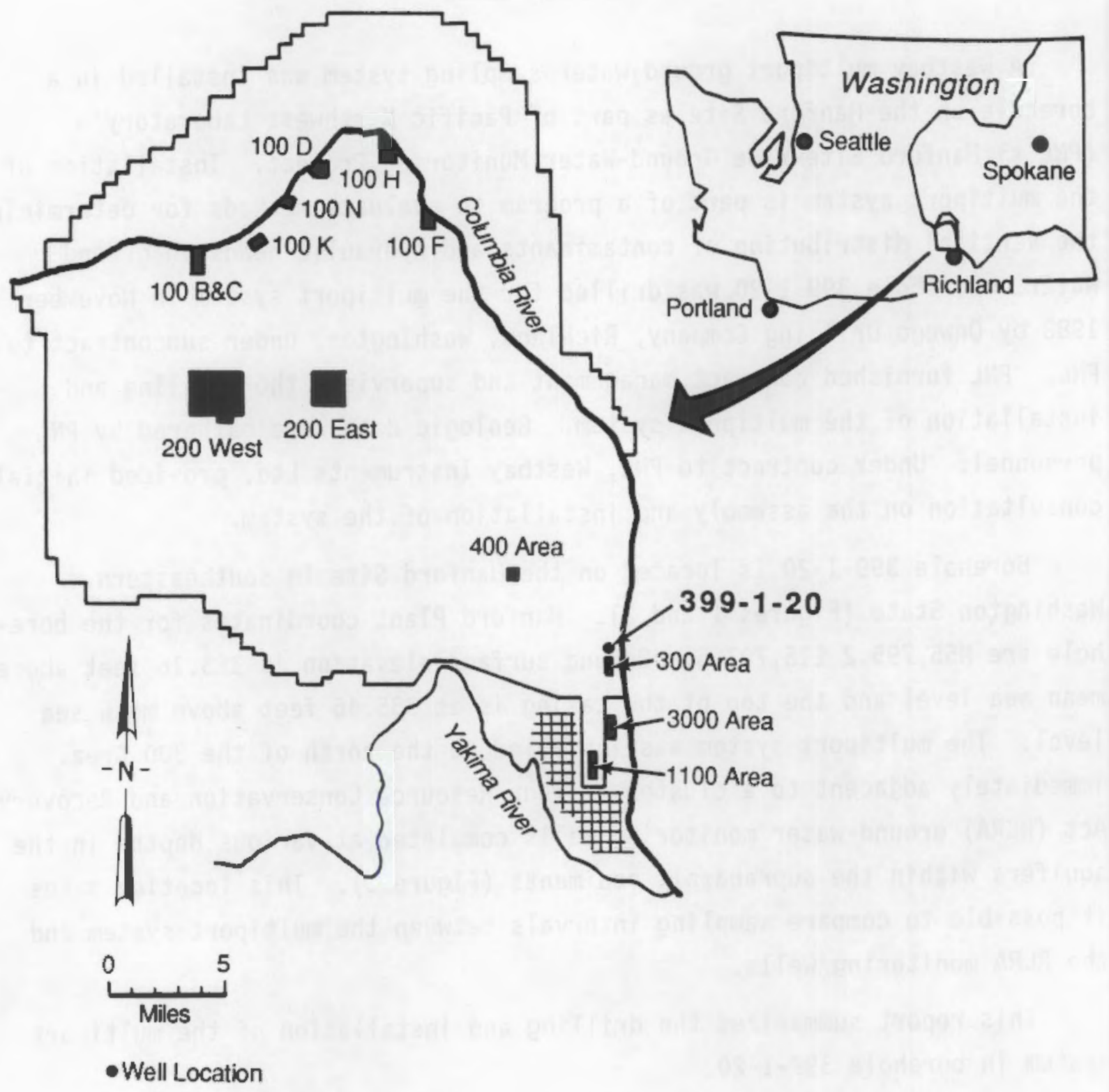

FIGURE 1. Location Map 


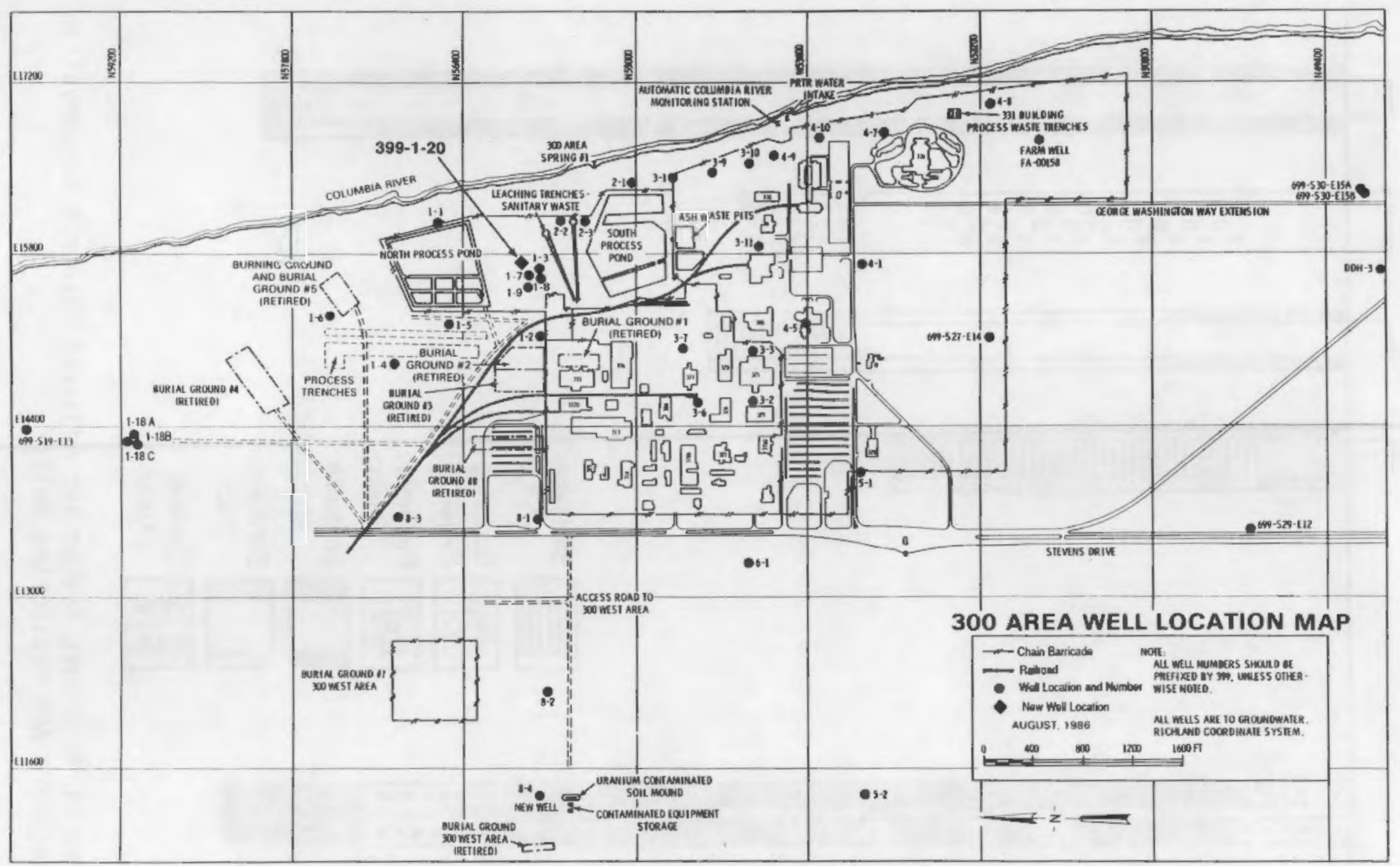

FIGURE 2. 300 Area Location Map 


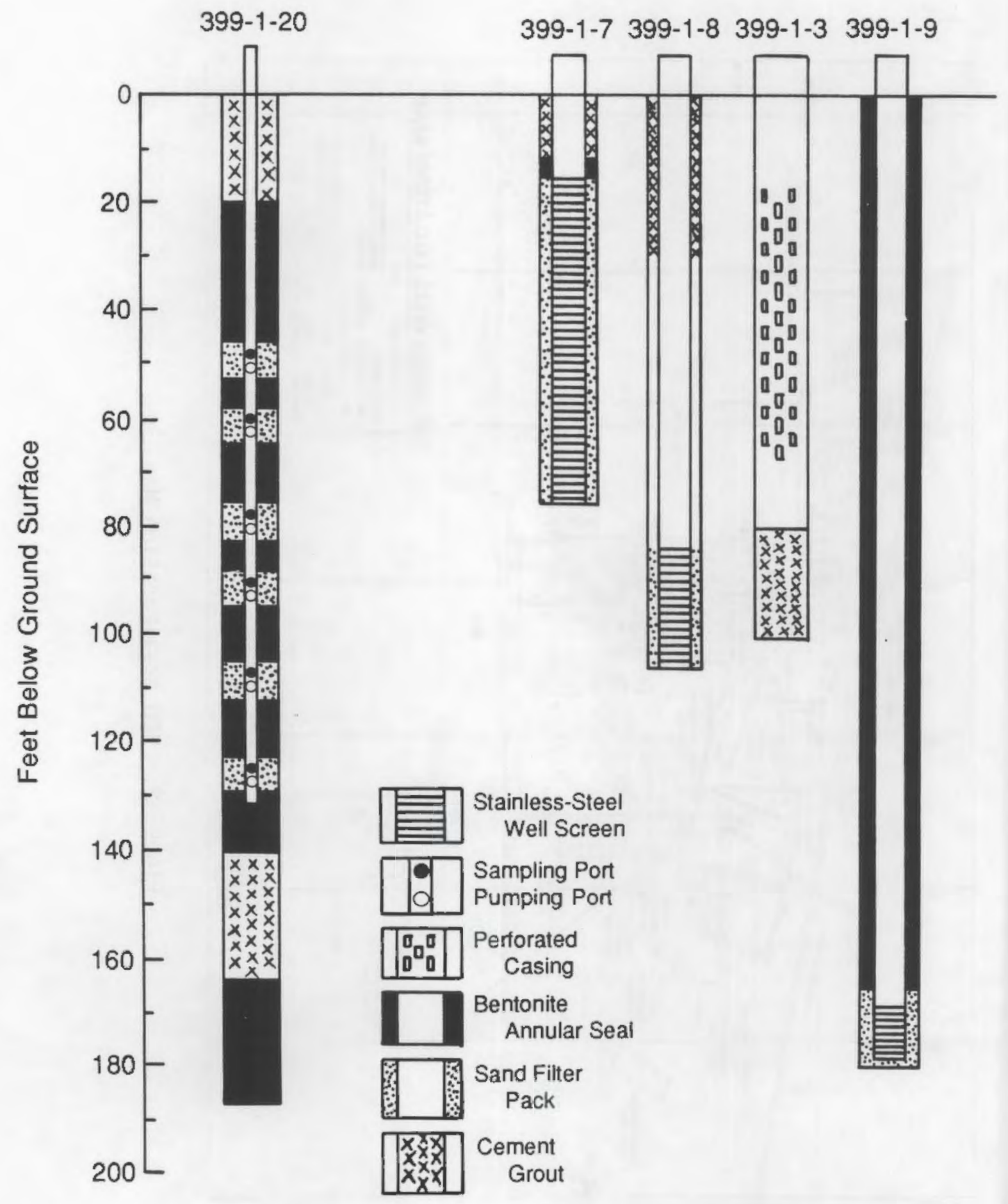

FIGURE 3. Diagram of Multiport System and Adjacent Resource Conservation and Recovery Act Monitoring Wells 


\section{CONCLUSIONS AND RECOMMENDATIONS}

\section{CONCLUSIONS}

The Westbay system is a multiport system that provides data on vertical ground-water contamination and hydraulic head distribution representative of formation conditions from a single borehole. The system's major advantage is its modular design, which allows versatile monitoring configurations that can be easily customized to any location and installed in a single well. Another advantage is that the samples and pressure measurements are taken outside the access tube through the sampling port. This eliminates the need to purge the access tube during sampling, and therefore the sample's fluid chemistry is not altered as a result of degassing, oxidation, biogenic activity, and precipitation. The lag time on fluid pressure measurements is also reduced relative to a conventional standpipe well. Additionally, the multiport system allows the integrity of coupling valves, joints, and the annular seals to be verified during installation and operation.

One of the major disadvantages of the system is that the operation of the system is labor intensive and requires substantial training. The installation of the system in a backfilling operation is also more difficult than conventional standpipe we 11 construction, because the multiple screened intervals and the polyvinylchloride (PVC) construction require additional protection during backfilling. In addition, very little maintenance can be performed after the system is installed by backfilling, and should the system components fail, the life span of the system would be curtailed.

\section{RECOMMENDATIONS}

A method for multiport installation should be developed in which the multiport system could be placed in a multiple-screened and cased well. Filter pack and bentonite seals would be placed between this casing and the borehole wall. The multiport system would be placed inside the casing, using packers to isolate sampling intervals (Figure 4). This type of installation would allow the system's components to be removed and repaired and would probably extend the useful life of the system. In addition, the multiport 


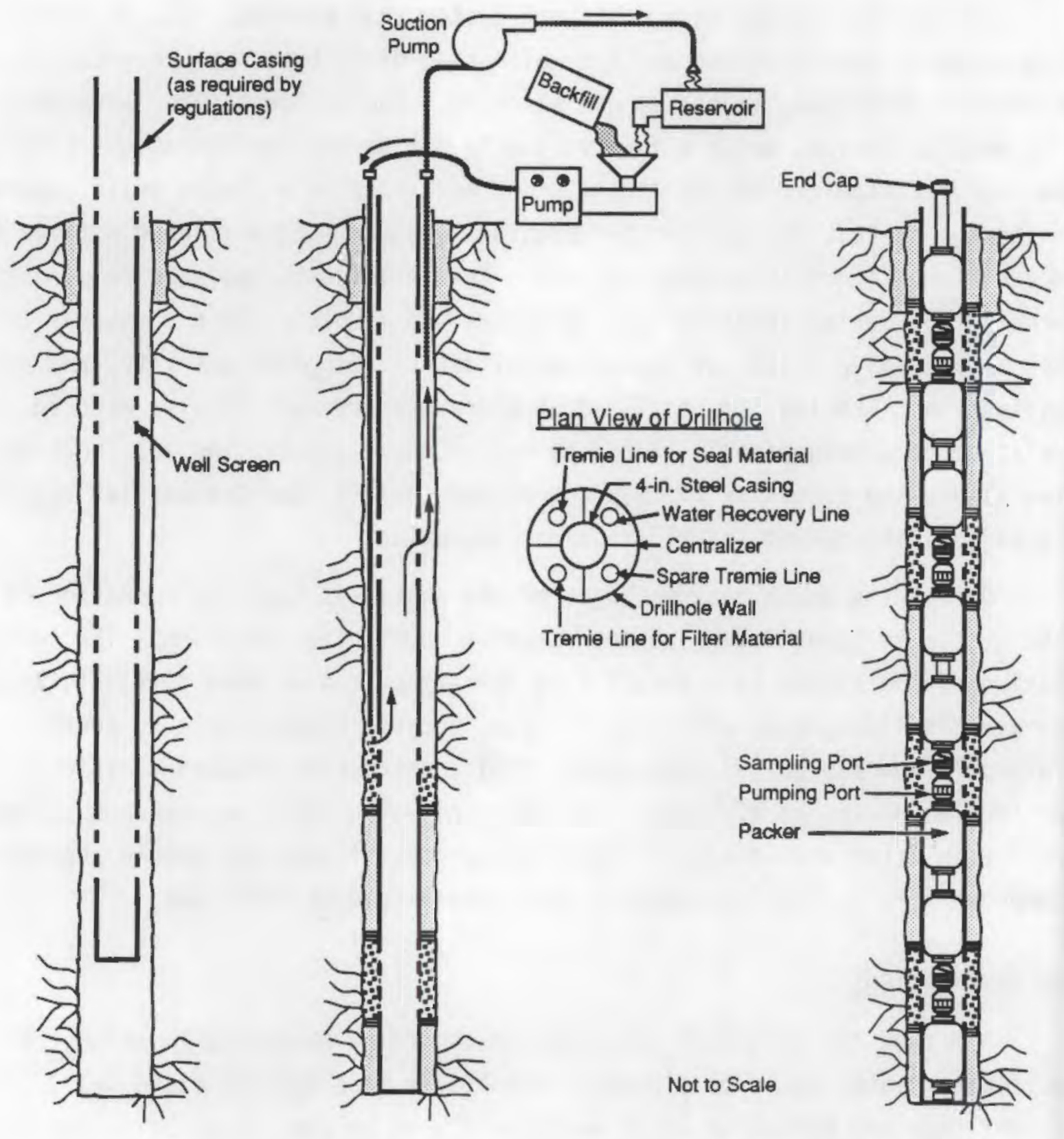

FIGURE 4. Installation of Multiport System in a Cased and Screened Well a) Placing 4-in. stainless-steel casing in well; b) Backfilling around 4-in. stainless-steel casing; c) Placing multiport system in well and inflating packers. (After drawings provided by Westbay Instruments, Inc.) 
system would not be subject to potential damage during the backfilling operation. A similar installation technique has been used successfully by Orange County Water District, California. 


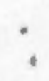




\section{GEOLOGY AND GEOPHYSICAL LOGGING}

The stratigraphy of borehole 399-1-20 closely correlates with that of the adjacent RCRA monitoring wells (399-1-9, 399-1-8, 399-1-7 and 399-1-6). Three major stratigraphic units were encountered during drilling: in ascending order, the Columbia River Basalt Group, the Ringold Formation, and the glaciofluvial/fluvial sediments. A lithology diagram is presented in the appendix.

The basalt was encountered at 176 feet below ground surface and basalt was present at the total depth of 187 feet. The basalt correlates with the Saddle Mountain Formation, which is the uppermost formation of the Columbia River Basalt Group identified in adjacent wells (Schalla et al. 1988). The basalt was black to blue gray, with abundant red iron staining and some sulfide coatings resembling pyrite. The basalt exhibited a very scoriaceous texture and contained approximately $5 \%$ caliche by volume. The caliche is suggested to be a surface-weathering product.

The Ringold Formation extended from 50 to 176 feet below 1 and surface and could be divided into two distinct lithologic units. The upper unit is predominantly composed of sandy gravels, and the lower unit is predominantly composed of silty clays. These units have been identified in the literature as the middle Ringold and the lower Ringold, respectively (Schalla et al. 1988). The upper, coarse-grained lithologic unit extends from 50 to 118 feet below ground surface and the lower, fine-grained unit ranges from 118 to 176 feet below ground surface. The upper sandy gravels contain a high percentage of basalt clasts, with smaller amounts of quartzite, feldspars, sandstones, and other lithoclasts. This unit can be texturally characterized as a mixture of sands, gravels, and small amounts (less than 10\%) of silt. The lower unit is composed predominantly of silts and clays. The silt and clay percentages of the samples ranged from $40 \%$ to $80 \%$. The $c l$ ay is estimated to be approximately $10 \%$ to $20 \%$ of the si1t/clay fraction, with a distinct layer of clay between 132 and 134 feet. A sample of wood was obtained from the 106- to 108-foot interval. Radiocarbon dating performed on the wood sample by Washington State University indicated a date of $>20,000$ years before present (see appendix). 
Undifferentiated glaciofluvial sediments occur between the surface and 50 feet below the surface. These sediments are composed of unconsolidated sands, gravels, and silts comprising mostly basaltic clasts, with a smaller portion of volcanic, metamorphic, and silica-rich grains. Thin beds averaging a foot in thickness are inferred from the behavior of the drill between 45 and 50 feet below the ground surface. This bedding is suggested to contain fining upward layers of gravels, sands, and silts.

Pacific Northwest Laboratory completed three geophysical logging runs on borehole 399-1-20. The first logging run was conducted on 0ctober 20, 1988, logging between 0 and 134 feet below surface with a natural gamma probe prior to setting the 10-in. diameter casing. The second logging run was conducted on October 24, 1988, using the natural gamma probe between 4 and 186 feet below surface. The well was not yet cased between 134 and 187 feet below surface, which allowed high-resolution logs to be taken in this interval. The natural gamma logs confirmed the lithologic variations and were used in the selection of sampling ports. The third logging run was conducted on November 2, 1988, using the density probe. The density probe provided information on the general condition of the well and was used to determine where the well might have caved in when the temporary casings were extracted. The geophysical logs are presented in the appendix. 


\section{DRILLING OPERATIONS}

Well 399-1-20 was drilled using a Bucyrus Erie 22-W cable tool drilling rig utilizing the hard tool method (Driscoll 1986). Drilling operations began on October 5,1988 , and continued until November 8,1988 , for a total of 26 days of drilling (Figure 5). The final depth of the well was 187 feet below land surface. Temporary telescoping carbon-steel 12-in.-diameter casing was placed from the surface to a depth of 133 feet and temporary carbonsteel 10-in.-diameter casing was placed from the surface to the total depth of 180 feet. A minimum $10-\mathrm{in}$. casing size was required to accommodate working room for the tremie pipe and protective casing around the multiport system during placement of the annular filter packs and seals.

The well was initially drilled to a total depth of 187 feet on 0ctober 21,1988 . While the 10-in. casing was being placed in the well after total depth was reached, the casing encountered resistance at a depth of

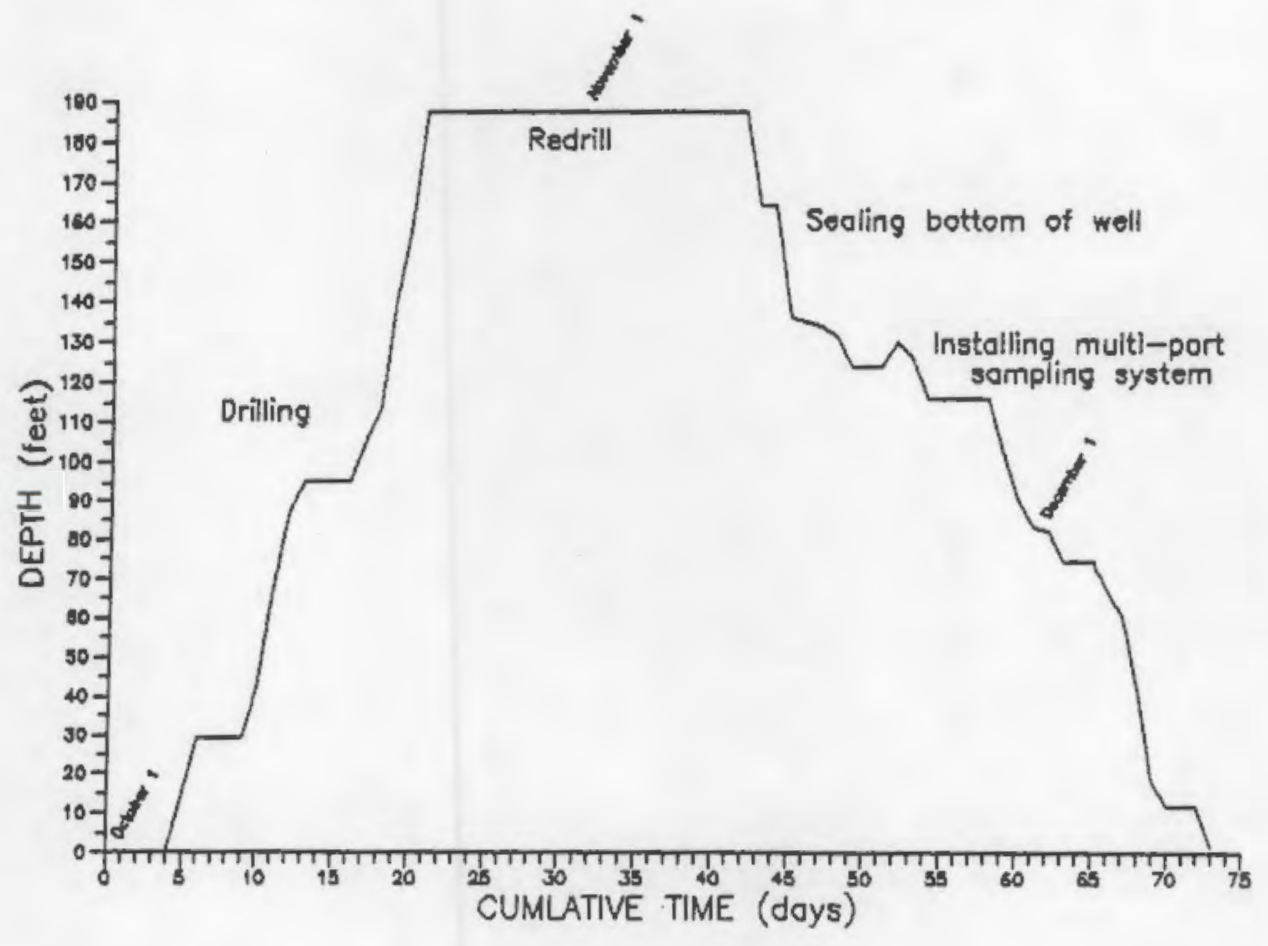

FIGURE 5. Construction Progress Curve 
approximately 160 feet in a predominantly clay and silt zone. It was determined that the end of the 10-in. casing had collapsed due to this resistance and required removal. The now-distorted end of the 10-in. casing prevented it from being drawn back up through the 12 -in. casing during removal. Therefore both the 10-in. and 12-in. casings had to be removed at the same time. After the casings were removed, the borehole partially filled with caved-in material. The well was then redrilled from a depth of approximately 15 feet to 187 feet. During redrilling, the original borehole was retraced to the final depth, as several facts indicated: 1) the redrilling rate was approximately twice as fast as the original drilling rate; 2) the casing could be driven in more easily during the redrilling; 3) sands and gravels were encountered in clay and silt formations, indicating that sands and gravels had caved in; 4) occasionally the drill bit would drop 0.5 to 4 feet through open hole during redrilling; and 5) the drill bit dropped through the basalt, indicating the original borehole had been retraced to the final depth in the basalt at 187 feet below ground surface. 


\section{COMPLETION AND INSTALLATION}

The multiport casing and port intervals were calculated and the pieces laid out in order on saw horses near the borehole. Each casing length was given a number sequentially from the bottom of the monitoring well, and an appropriate coupling was attached to the top of each casing. All casing lengths were measured and recorded (see appendix). The multiport components were protected by plastic shipping covers until installation. Casing lengths were 10 feet or less, in divisions of 5 feet, 2 feet, and 1 foot. The multiport system was constructed of 1.5-in. inside diameter (ID) PVC pipe with well screens that measured 2.88-in. outside diameter (OD). The multiport system was assembled as it was placed in the well inside a 4-in. Schedule-80 PVC protective casing. This protective casing was used to protect the multiport system and keep the screens free of seal material. A centralizer was placed 10 feet from the bottom of the protective casing to center the multiport system in the wel1. As the multiport system was placed in the well, each assembled joint was hydraulically tested by application of a minimum internal pressure of 100 psi. After the multiport system was properly positioned and secured, the annular seal materials were placed around it.

During backfilling, the temporary carbon-steel casing was slowly removed, always leaving-a minimum of 1 to 2 feet of overlap of backfill material in the temporary carbon-steel casing. The temporary casing was removed using a cable-tool rig. This method of removal was awkward, requiring the use of three cable lines on the rig. One line was used to hold the tremie pipe, the second to hold the protective casing, and the third to pull the casing (Figure 6 ). In future wells, the temporary casing could be removed using hydraulic jacks, thus freeing one of the cable lines, allowing more working room in the casing, and reducing the chances of damaging the multiport system during withdrawal of the casing. When the temporary carbonsteel casing was cut with an acetylene cutting torch, the protective casing around the multiport system was shielded from the heat. Both a metal oversleeve and 4-in.-diameter steel pipe that was adapted to screw into the 4-in.-diameter PVC pipe were used. The adapted 4-in. steel pipe was considered the easier to use. 


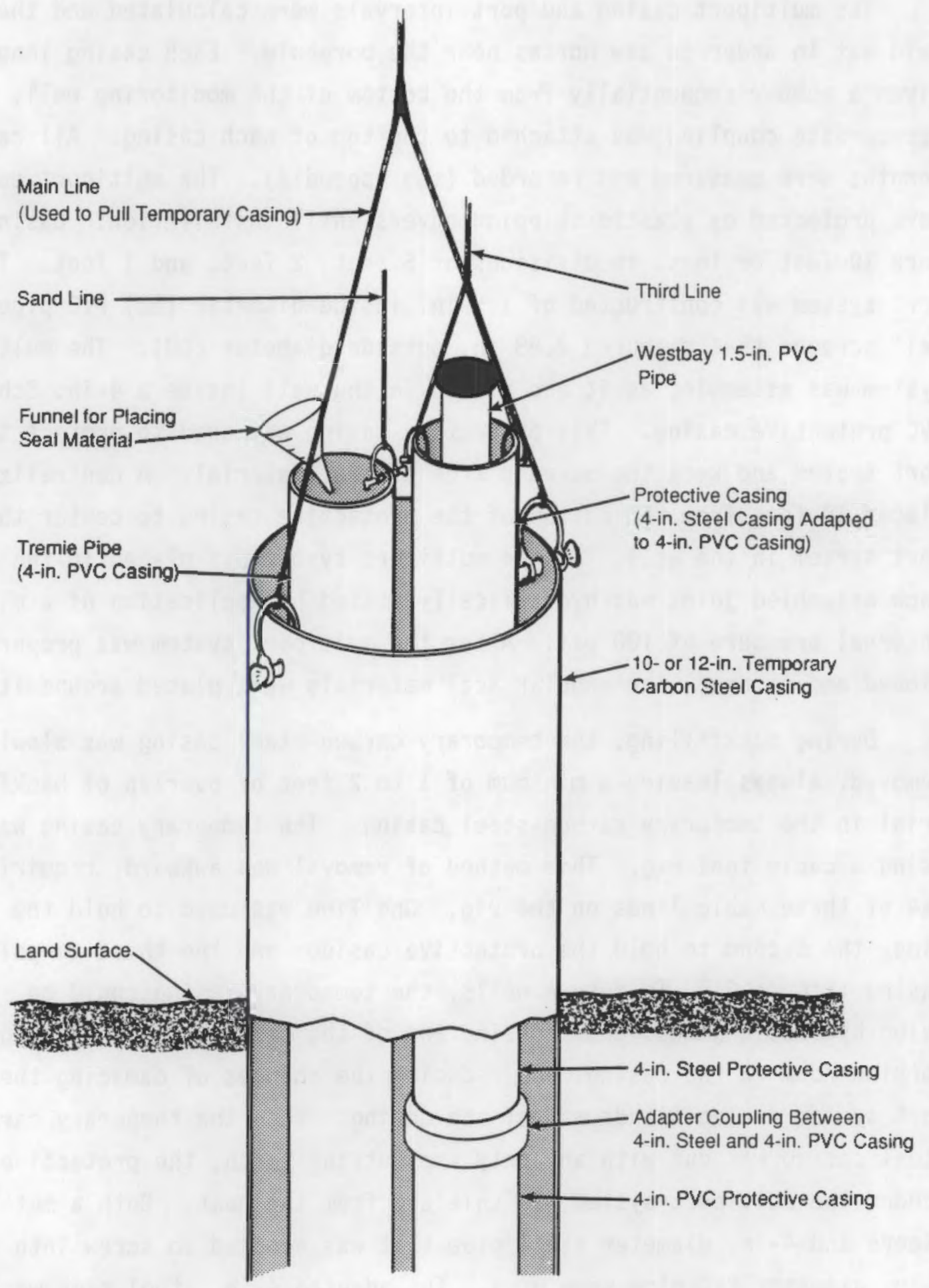

FIGURE 6. Completion Arrangement at the Well Head 


\section{FILTER PACK AND ANNULAR SEAL MATERIALS}

The bottom 55 feet of the well (between 132 and 187 feet) was abandoned and sealed to ensure that isolation was maintained between the unconfined and uppermost confined aquifers. The seal consisted of a layer of bentonite clay from 187 to 164 feet, a layer of Portland cement with $10 \%$ bentonite from 164 to 140 feet, and another layer of bentonite clay from 140 to 132 feet. The multiport system was then completed from 132 feet up to the surface.

Six sampling ports were placed, at 120.4 feet, 103.4 feet, 86.4 feet, 74.36 feet, 56.32 feet, and 44.3 feet below land surface. Backfill around the sampling ports was 20-40 mesh Colorado Silica Sand emplaced by gravity feed. Each sampling port has approximately 2.5 feet of this sand filter pack above it and 4.5 feet of sand filter pack below it, for a total sampling interval of approximately 7 feet (Figure 7). Medium-size Enviroplug bentonite crumble chunks were placed between the sand filter packs as a seal to isolate each sampling interval. The medium-size Enviroplug is composed of irregularly shaped bentonite pieces that range in size from 0.25 to 1.0 in. Enviroplug was chosen over bentonite pellets because the quality of the pellets that were purchased at approximately the same time as the construction of this well were poor, and often moisture had entered the packaging. It was determined in construction of other wells that the Enviroplug did not become as sticky on the surface as quickly as the peilets, and therefore "bridging" or clogging inside the temporary casing was minimized. The minimum thickness of the bentonite seals between the ports was 3.9 feet between ports 3 and 4 ; the seal was up to 10.8 feet thick between ports 1 and 2 . The seals were determined to be effective by differences in the pressure transducer readings at each port (Figure 8 ). Before being placed in the well, the Enviroplug was sieved through a coarse mesh screen to remove the fines. Sieving the fines from the bentonite chunks decreased the chance of bridging at the water table. A 4-in. PVC tremie pipe was used to place the bentonite seal. Use of the tremie pipe prevented bridging inside the temporary carbon-steel casing. Such bridging would have had the potential to compromise the multiport system. Any bridging that does occur will occur in the tremie pipe, which can be removed easily from the borehole and cleaned. The bentonite chunks were 


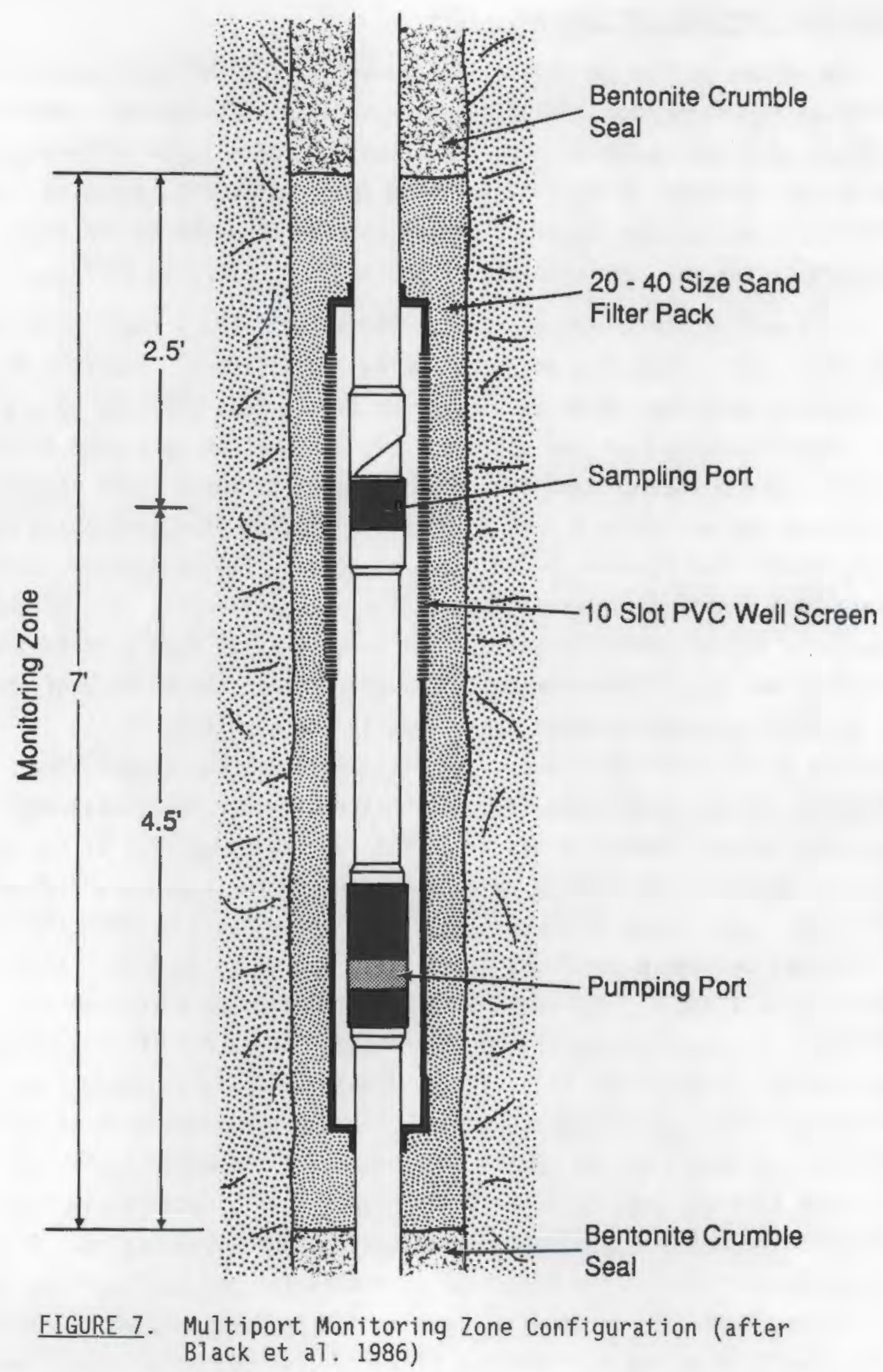




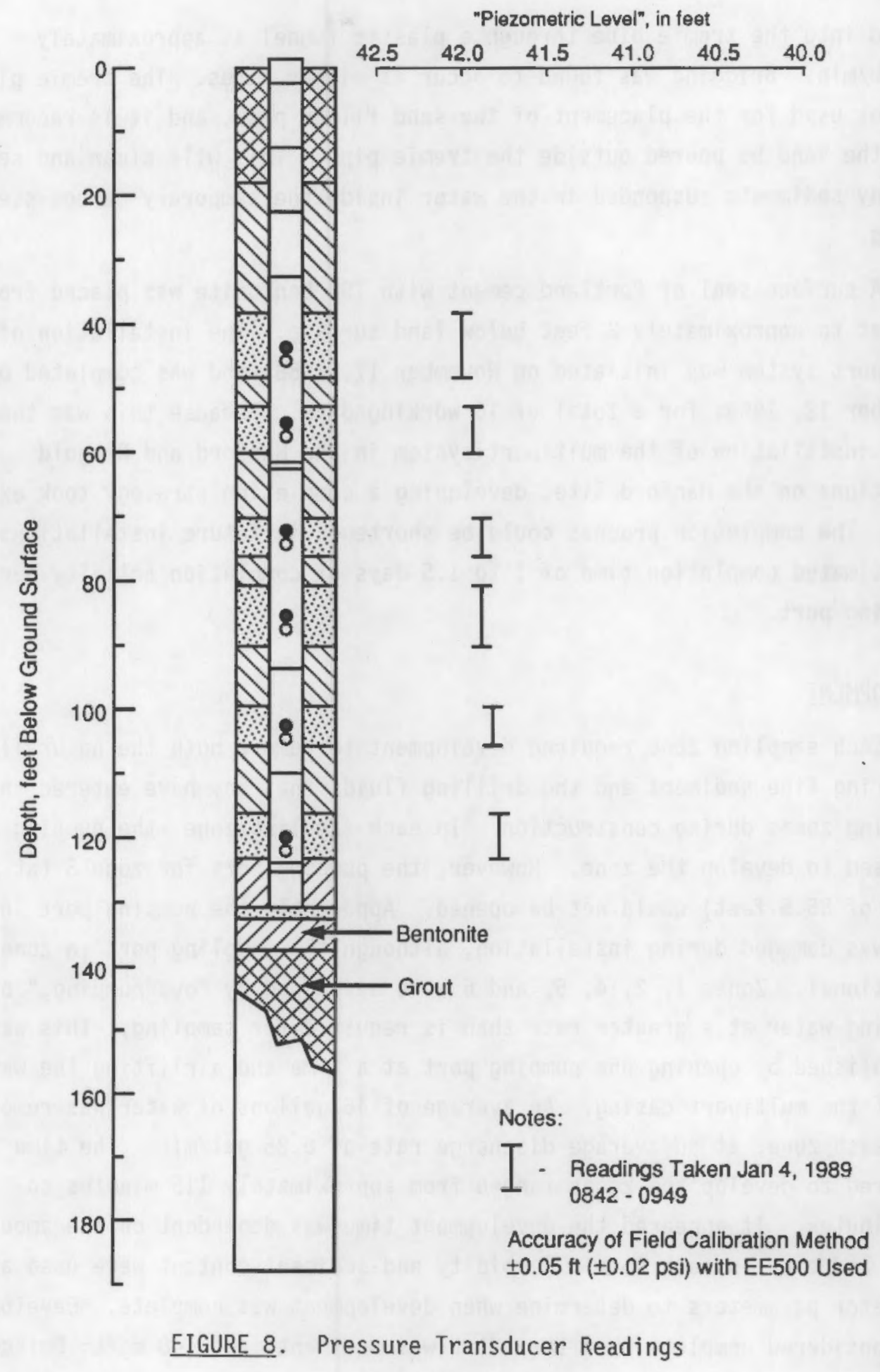


poured into the tremie pipe through a plastic funnel at approximately $2.5 \mathrm{lb} / \mathrm{min}$. Bridging was found to occur at higher rates. The tremie pipe was not used for the placement of the sand filter pack, and it is recommended that the sand be poured outside the tremie pipe. This will clean and settle out any sediments suspended in the water inside the temporary carbon-steel casing.

A surface seal of Portland cement with $10 \%$ bentonite was $\mathrm{placed}$ from 20 feet to approximately 3 feet below land surface. The installation of the multiport system was initiated on November 11, 1988, and was completed on December 12, 1988, for a total of 16 working days. Because this was the first installation of the multiport system in the Hanford and Ringold Formations on the Hanford Site, developing a completion strategy took extra time. The completion process could be shortened in future installations to an estimated completion time of 1 to 1.5 days of completion activity per sampling port.

\section{DEVELOPMENT}

Each sampling zone required development to remove both the naturally occurring fine sediment and the drilling fluids that may have entered the sampling zones during construction. In each sampling zone, the pumping port was used to develop the zone. However, the pumping port for zone 3 (at a depth of 85.5 feet) could not be opened. Apparently the pumping port in this zone was damaged during installation, although the sampling port in zone 3 is operational. Zones $1,2,4,5$, and 6 were developed by "overpumping, " or removing water at a greater rate than is required for sampling. This was accomplished by opening one pumping port at a time and airlifting the water out of the multiport casing. An average of 46 gallons of water was removed from each zone, at an average discharge rate of $0.25 \mathrm{gal} / \mathrm{min}$. The time required to develop the zones ranged from approximately 115 minutes to 692 minutes. It appeared the development time was dependent on the amount of silts and clay in each zone. Turbidity and sediment content were used as the indicator parameters to determine when development was complete. Development was considered complete when the water was sediment free $(<8 \mathrm{mg} / \mathrm{L}$; Driscoll 1986) and turbidity values were below 10 NTU. The Technical Enforcement 
Guidance Document (EPA 1986) for RCRA monitoring suggests that turbidity values should be less then 5 NTU when obtainable. However, given the extremely low discharge rates obtainable by this method of development, the length of time and amount of water that would be required to reach a value below 5 NTU in most cases made this measure impractical. The rates and values are sumarized in Table 1.

TABLE 1. We11 Development

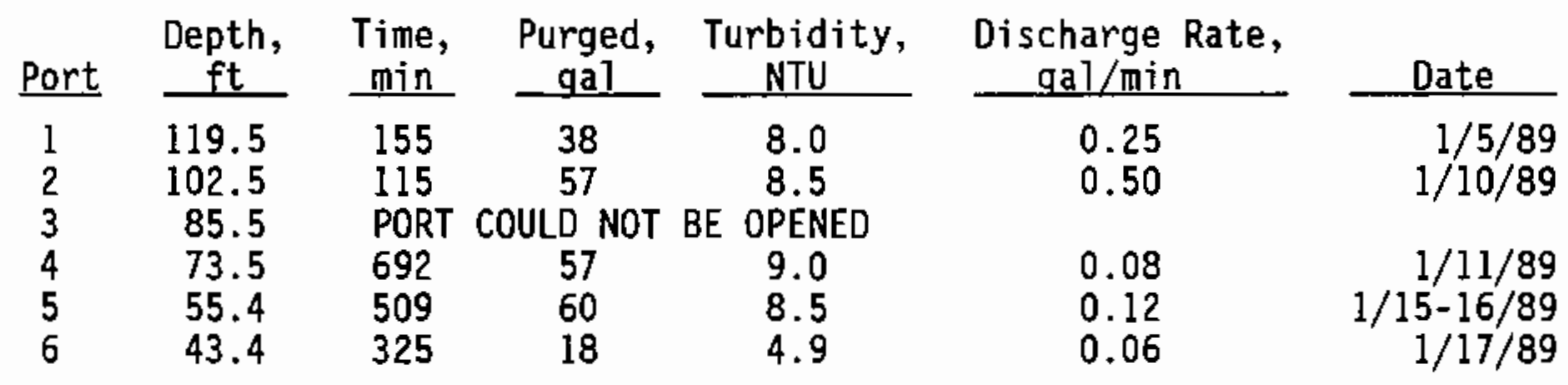




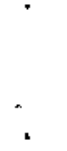




\section{REFERENCES}

Black, W. H., H. R. Smith, and F. D. Patton. 1986. "Multiple-Level GroundWater Monitoring with the MP System." Paper presented at the Surface and Bore Hole Geophysical Methods and Ground Water Instrumentation Conference and Exposition, October 1986, Denver, Colorado.

Driscol1, F. G. 1986. Groundwater and Wel1s. Johnson Division, St. Paul, Minnesota.

Schalla, R. 1988. Interim Characterization Report for the 300 Area Process Irenches. PNL-6716, Pacific Northwest Laboratory, Richland, Washington.

U.S. Environmental Protection Agency (EPA). 1986. Resource Conservation and Recovery Act (RCRA) Ground-Water Monitoring Technical Enforcement Guidance Document. OSWER-9950.1, Office of Waste Programs Enforcement, U.S. Environmental Protection Agency, Washington, D.C. 

APPENDIX

WELL LOGS AND OTHER RECORDS 


\section{APPENDIX}

\section{WELL LOGS AND OTHER RECORDS}

This appendix contains the as-built diagrams, completion/inspection reports, casing length measurement record, radiocarbon dating results, natural gamma log with the lithology and port intervals, and geophysical logs.

A.1 


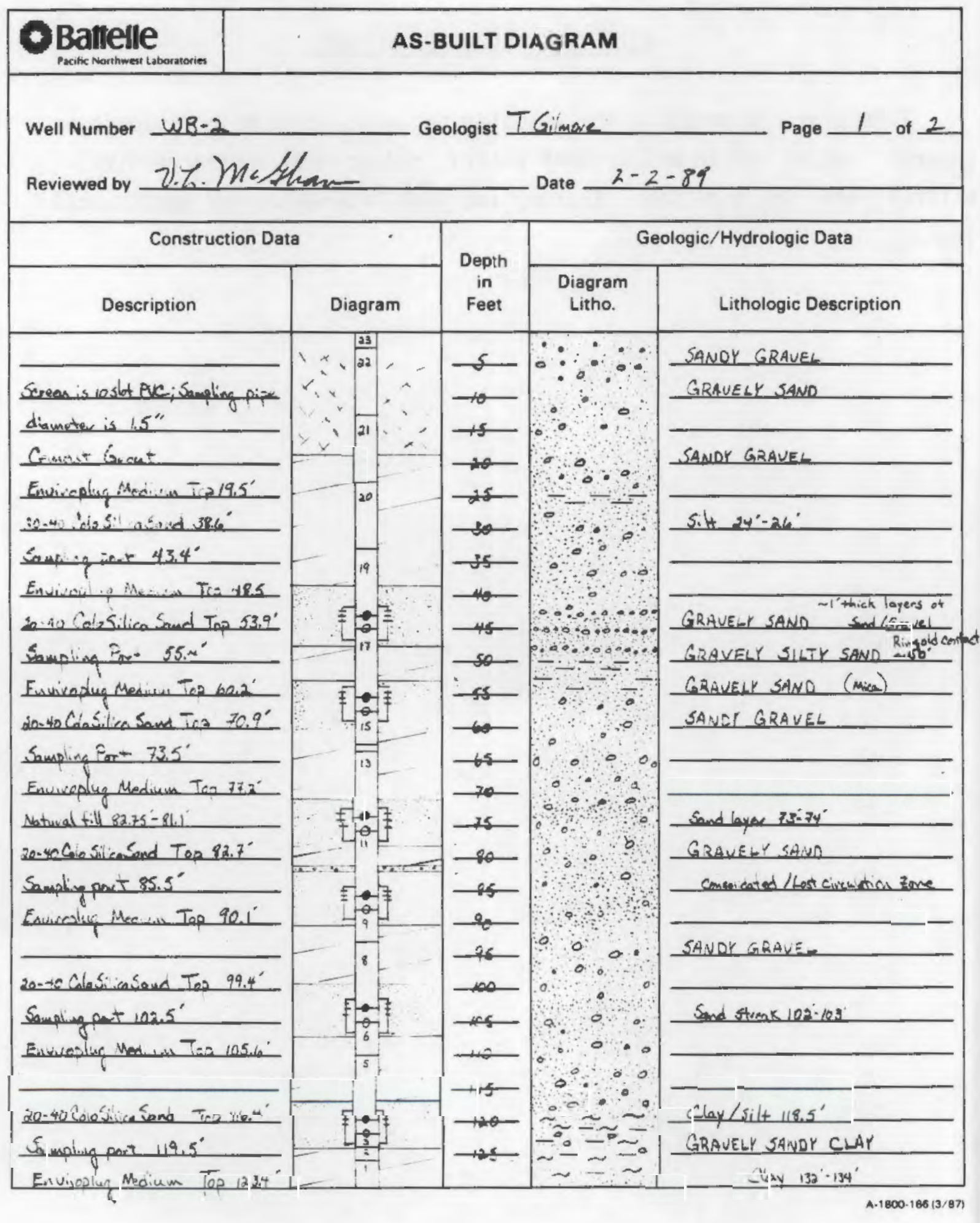




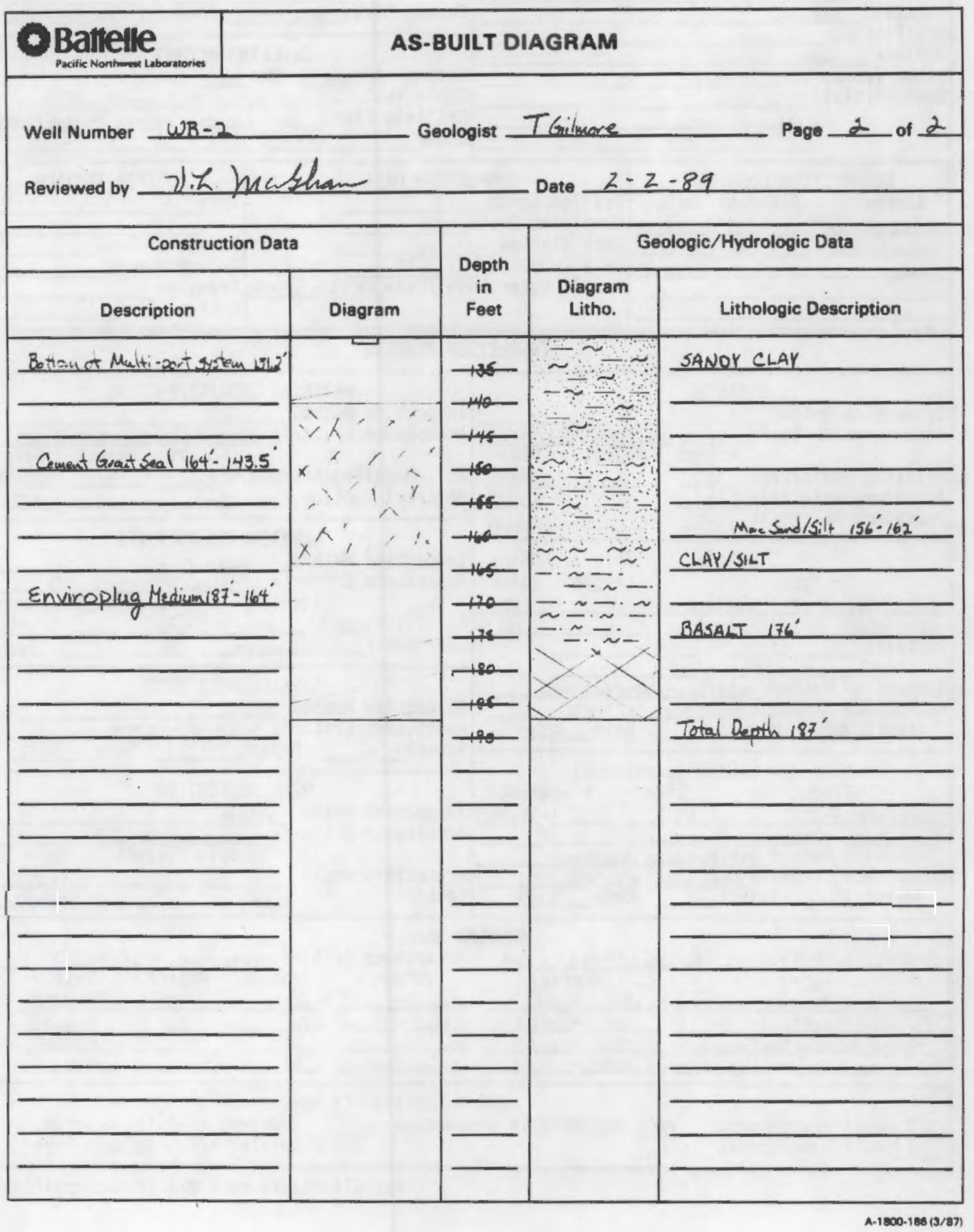




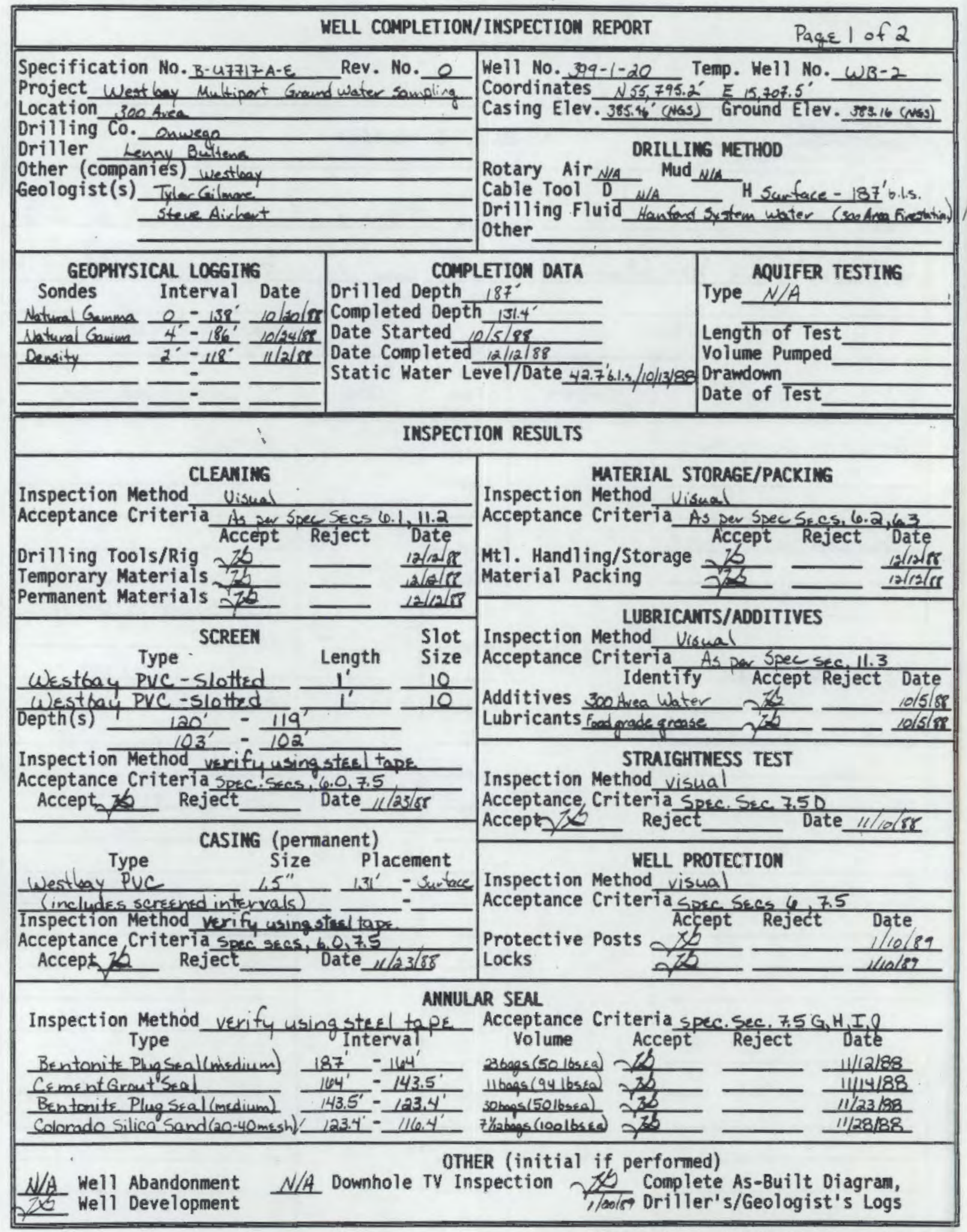

For all blanks mark $N / A$ if not applicable. 


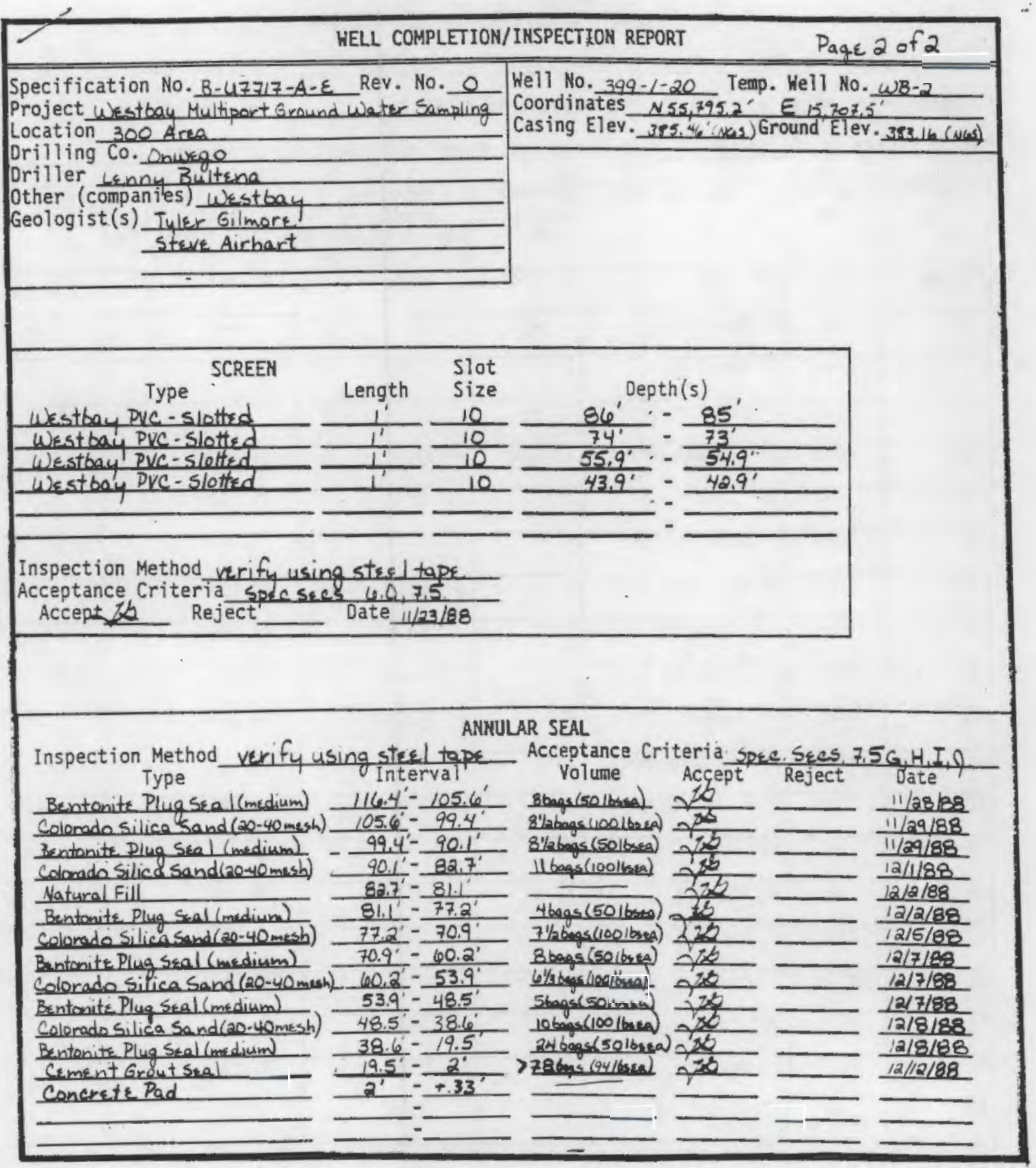


CASING LENGTH MEASUREMENT RECORD

Project: Battelle PNL

Location: 300 Area
Date: November 20, 1988

Drillhole No.: HB-2
Project No.:

Nominal B.O.H.: $131.2^{\prime}$

Casing Size/Type: 1.5" MP

Measured by: Kurt Seechouse \& Steve Airhart

\begin{tabular}{|c|c|c|c|c|c|c|}
\hline $\begin{array}{l}\text { Section } \\
\text { No. }\end{array}$ & $\begin{array}{c}\text { Serial } \\
\text { No. }\end{array}$ & Description & $\begin{array}{l}\text { Nominal } \\
\text { Length, } \\
\mathrm{ft} .\end{array}$ & \begin{tabular}{|c|} 
Measured \\
Length. ft \\
Top of Coupling
\end{tabular} & $\begin{array}{l}\text { Cumulative } \\
\text { Length. ft } \\
\text { Top of Coupling }\end{array}$ & $\begin{array}{l}\text { Magnetic } \\
\text { Collars }\end{array}$ \\
\hline Bottom & $\cdots$ & End Cap & " $3 / 4^{\prime \prime}$ & $113 / 4^{\prime \prime}$ & $0.146^{\prime}$ & $.292^{\prime} 31 / 2$ \\
\hline 1 & -- & $5^{\prime}$ Coupling & $\cdots$ & $\cdots$ & -- & $\cdots$ \\
\hline 2 & - & $2^{\prime}$ Coupling & $7^{1}$ & $7^{\prime} 4 / 16^{\prime \prime}$ & $7.167^{\prime}$ & - \\
\hline$\overline{3}$ & 2119 & 2' Pumping Port & - & -- & -- & $8.17^{\prime}$ \\
\hline 4 & 4069 & 2' Measure. Port & $4^{\prime} 3 / 4^{\prime \prime}$ & $4^{\prime} 3 / 16^{\prime \prime}$ & $11.183^{\prime}$ & -- \\
\hline 5 & -- & $10^{\prime}$ Coupling & $10^{\prime}$ & $10^{\prime} 0^{\prime \prime}$ & $21.183^{\prime}$ & -- \\
\hline 6 & 2116 & $5^{\prime}$ Pumping Port & $5^{\prime}$ & - & -- & $25.18^{\prime}$ \\
\hline 7 & 4067 & $2^{\prime}$ Measure. Port & $2^{\prime}$ & $7^{\prime} 2 / 16^{\prime \prime}$ & $28.193^{\prime}$ & $\cdots$ \\
\hline 8 & -- & $10^{\prime}$ Coupling & $10^{\prime}$ & $10^{\prime} 1 / 16^{11}$ & $38.199^{\circ}$ & -- \\
\hline 9 & 2115 & $5^{\prime} \quad$ Pumping Port & $5^{\prime}$ & -- & -- & $42.20^{\prime}$ \\
\hline$\overline{10}$ & 4066 & $2^{\prime}$ Measure. Port & $2^{\prime}$ & $7^{\prime} 3 / 16^{\prime \prime}$ & $45.214^{\prime}$ & $\cdots$ \\
\hline$\overline{11}$ & 2118 & $10^{\prime}$ Pumping Port & $10^{\circ}$ & $10^{\prime} 4 / 16^{\prime \prime}$ & $55.235^{\prime}$ & $54.235^{\prime}$ \\
\hline$\overline{12}$ & 4065 & $2^{\prime}$ Measure. Port & $2^{\prime}$ & $2^{\prime} 1 / 16^{\prime \prime}$ & $57.240^{\prime}$ & -- \\
\hline$\overline{13}$ & -- & $10^{\prime}$ Coupling & $10^{\prime}$ & $\cdots$ & - & - \\
\hline$\overline{14}$ & -- & $1^{\prime}$ Coupling & $1^{\prime}$ & $11^{\prime} 4 / 16^{\prime \prime}$ & $68.256^{\prime}$ & $\cdots$ \\
\hline$\overline{15}$ & 2102 & $5^{\prime}$ Pumping Port & $5^{\prime}$ & $\overline{--}$ & - & $72.27^{\prime}$ \\
\hline$\overline{16}$ & 4064 & $2^{\prime}$ Measure. Port & $2^{\prime}$ & $7^{\prime} 4 / 16^{\prime \prime}$ & $75.277^{1}$ & -- \\
\hline 17 & 2120 & 10' Pumping Port & $10^{4}$ & $10^{\prime} 2 / 16^{\prime \prime}$ & $85.287^{\prime}$ & $84.28^{\prime}$ \\
\hline$\overline{18}$ & 4068 & $2^{\prime}$ Measure. Port & $2^{\prime}$ & $2^{1} 2 / 16^{\prime \prime}$ & $87.297^{\prime}$ & $\cdots$ \\
\hline 19 & -- & $10^{\prime}$ Coupling & $10^{1}$ & $10^{\prime} 2 / 16^{\prime \prime}$ & $97.308^{\prime}$ & -- \\
\hline 20 & -- & $10^{\prime}$ Coupling & $10^{\prime}$ & $10^{\prime} 2 / 16^{\prime \prime}$ & $107.318^{\prime}$ & - \\
\hline 21 & -- & $10^{\prime}$ Coupling & $10^{\prime}$ & $10^{\prime} 2 / 16^{\prime \prime}$ & $117.329^{1}$ & -- \\
\hline 22 & $\cdots$ & $10^{\prime}$ Coupling & $10^{\prime}$ & $10^{\prime} 2 / 16^{\prime \prime}$ & $127.339^{\prime}$ & -- \\
\hline 23 & -- & $5^{\prime}$ Coupling & $5^{\prime}$ & $5^{\prime} 1 / 16^{\prime \prime}$ & $132.344^{1}$ & 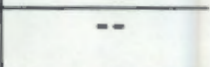 \\
\hline 24 & - & $2^{\prime}$ Coupling & $2^{\top}$ & $2^{\prime} 1 / 16^{\prime \prime}$ & $134.349^{1}$ & -- \\
\hline 25 & -- & 1' No Coupling & $1^{\prime}$ & $6^{\prime} 9 / 16^{\prime \prime}$ & $134.896^{\prime}$ & $\cdots$ \\
\hline
\end{tabular}

A. 6 


\title{
WASHINGTON STATE UNIVERSITY
}

\author{
Department of Chenical Engineering Pullman, Washington $99164-2710 \quad 509-335-4332$
}

\section{RADIOCARBON DATING LABORATORY}

\author{
WASHINGTON STATE UNIVERSITY \\ Pullman, Washington, 99164-2710 \\ Office: (509) 335-4731 \\ Lab: (509) 335-2417
}

\section{SAMPLE REPORT FORM - EINAL REPORT}

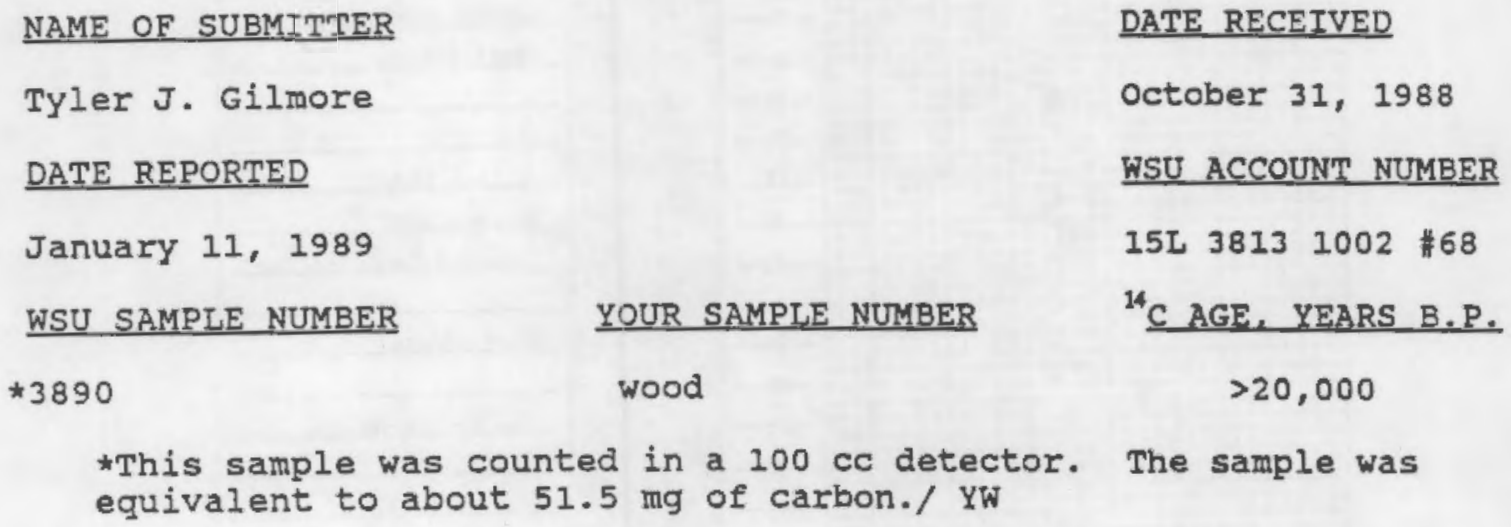

Sample Processed by: Sample Calculated by:

Welter

Welter/Sheppard

Sample Reported by:

Sheppard

NOTE: All analyses are based upon the Libby half-life ( $5570 \pm 30$ years) for radiocarbon. To convert ages to the half-life of 5730 years, multiply the age given above by 1.03 . Zero age date is A.D. 1950. (Reference: Editorial Comment, RADIOCARBON, Vol. 7, 1965.) 


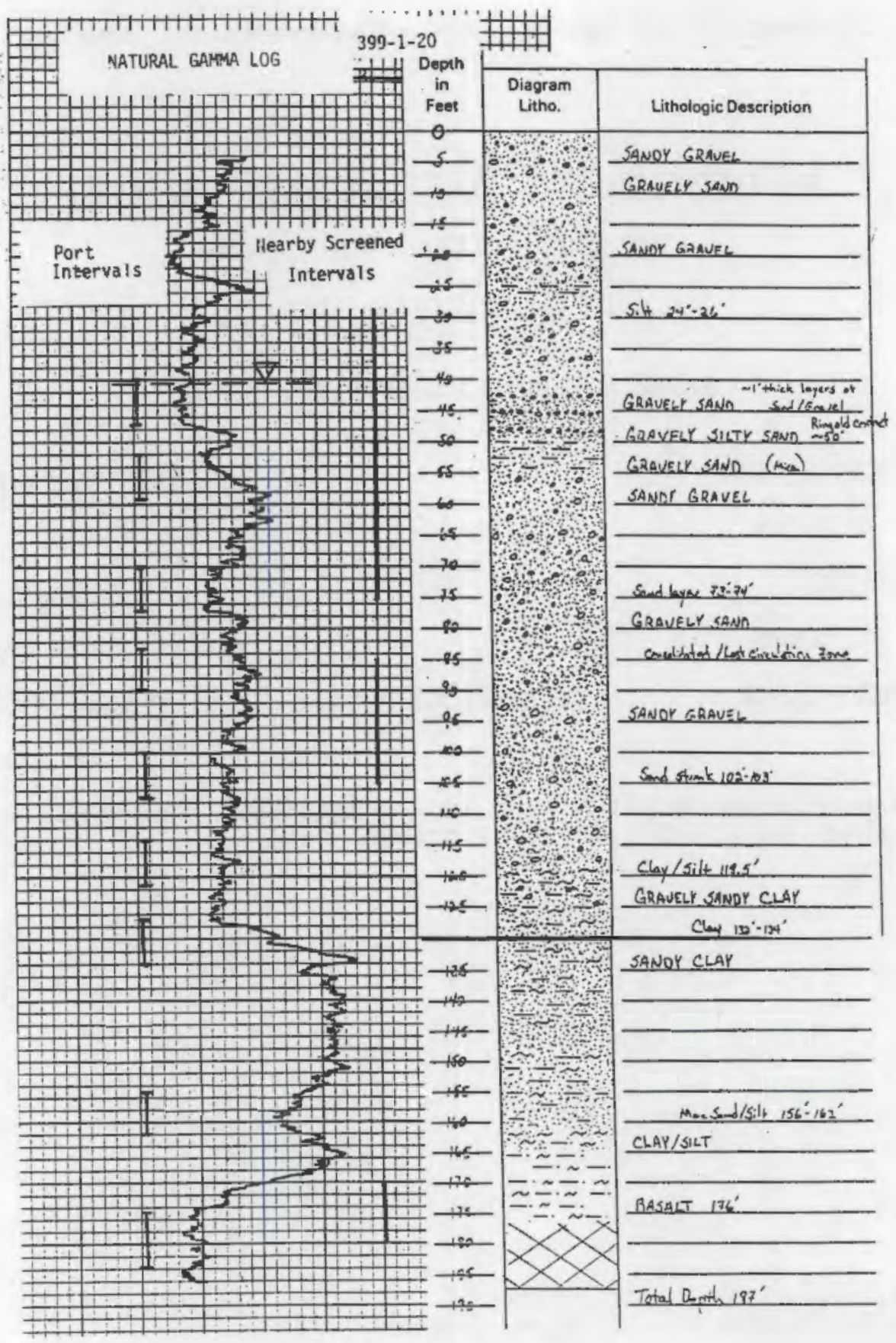


1

\begin{tabular}{|c|c|c|c|c|c|c|c|c|c|c|c|c|c|c|c|c|c|c|}
\hline -. & & & $\ldots$ & & $y$ & $=$ & - & $\cdots$ & & $\cdots$ & & $\ldots$ & & & & & & \\
\hline 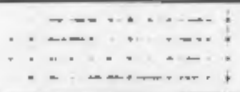 & $\rightarrow-$ & 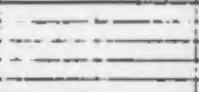 & $\underline{-1}$ & $z: \ldots$ & ..... & 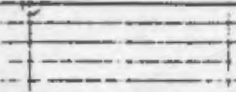 & 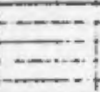 & $=1$ & $z$ & 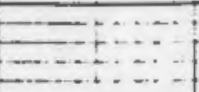 & 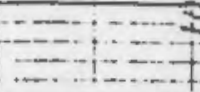 & $y \div=$ & & an & 10 & & & \\
\hline 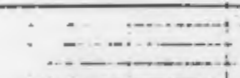 & & $E$ & $E=-+$ & E & +1 & 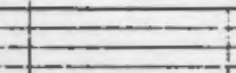 & & & & -- & $z$ & 5 & & + & & & & \\
\hline & - & & $-1-1$ & $E \cdots$ & $-\cdots \cdots$ & & & & & & 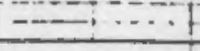 & & & 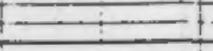 & & & & \\
\hline$=$ & & $=$ & $=-$ & $\cdots$ & $=$ & $E$ & & $E$ & & $\cdots$ & 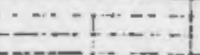 & $-2=-1$ & & 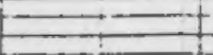 & & & & \\
\hline$-\ldots$ & 三 & & $\square+\square$ & 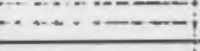 & 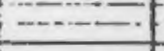 & 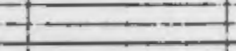 & & E & te & $=-$ & $=$ & $\cdots+\cdots$ & & $\cdots$ & & & & \\
\hline$-+=$ & $=$ & Z & $9+1$ & $-x--1$ & $=0$ & $E$ & $=$ & 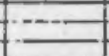 & & $\ldots \mathrm{H}$ & $\cdots$ & $x-1=-$ & & $=$ & $E$ & & $=$ & \\
\hline$=$ & $=$ & $=1 \ldots$ & -1, & $60=$ & $E-\cdots$ & $=$ & & $=$ & $=$ & $=-1-2$ & $=$ & 0 & $-\cdot$ & $2-1$ & $=$ & & $\cdots$ & \\
\hline$\ldots$ & & 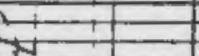 & $4: 5$ & $\cdots i$ & -1 & - & & & & $E$ & $=$ & $\cdots$ & & $=$ & & & & \\
\hline$\div \quad$ & & $7+1$ & $+1=\frac{-1}{1}$ & $8=$ & $\cdots-1$ & $\square$ & & & $=$ & 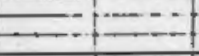 & $\cdots$ & 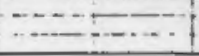 & & $=1$ & $\Longrightarrow$ & - & $\cdots$ & \\
\hline$=$ & - & $=0$ & $+2 y^{2}$ & $30-1$ & $\Rightarrow$ & $=$ & 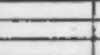 & & $=$ & 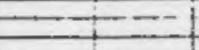 & -- & $\because=\cdots$ & & $=$ & $=$ & & $-i-i$ & \\
\hline${ }_{-}$ & 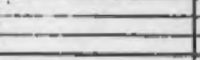 & $=-9$ & In $n$ & $E$ & & & & $E+$ & & $=$ & $=$ & $0+1$ & & $5+1$ & 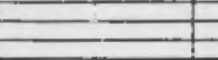 & $E$ & 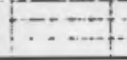 & \\
\hline$=$ & $=$ & 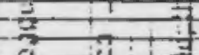 & 11 & $I$ & $=\ldots$ & 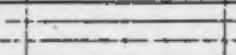 & & $=$ & & $=1$ & $\cdots=-1$ & $-\cdots:-1$ & & $5+$ & $=$ & & $=--$ & \\
\hline$-\infty$ & & 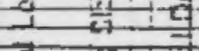 & 41 & $=-1 \cdots$ & $\cdots$ & $-\ldots$ & & + & - & -1 & +1 & - & $E$ & $-=$ & $\ldots$ & & & \\
\hline$=$ & $=$ & $=0$ & $6 \frac{1}{3}=3$ & $-3-0-1$ & $\cdots \rightarrow$ & $=\div$ & & & $E$ & $=-1$ & $\because 1$ & $\because-0=1$ & & 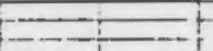 & $x-1$ & -1 & $=1$ & \\
\hline$=$ & & $5-4$ & $0 \quad 3$ & 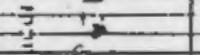 & $-\cdots$ & $\ldots$ & & 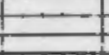 & - & $\Longrightarrow$ & $=-1--1$ & $\therefore$ & & 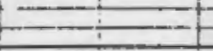 & $=$ & & $=\ldots$ & \\
\hline 61 & $E$ & 5 & $\mathrm{~F}-1$ & $-\frac{1}{3}-1$ & -1 & -5 & & & E & 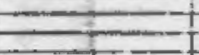 & $=$ & $=+\cdots$ & & -1 & 6 & & $+\cdots=-$ & \\
\hline$=$ & 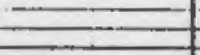 & -52 & $\because-1-1$ & $+95=$ & $=-4$ & $=$ & & $=$ & E- & $0+1$ & $\cdots--$ & $-1+\cdots$ & $\cdots$ & 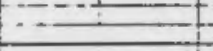 & $-7-5=1$ & $E$ & $=-+$ & \\
\hline 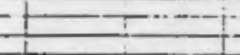 & -1 & $y-a$ & $=1-1$ & 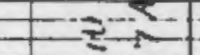 & -... & $=$ & $=$ & $=$ & $=$ & $=+\ldots$ & $=-1$ & $\cdots \cdots$ & - & $\ldots$ & + & & $=$ & \\
\hline$-i$ & $\Rightarrow$ & 102 & $5 !$ & 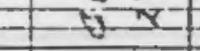 & $=-7$ & & & & & $=1=-1$ & 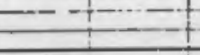 & $-\div-1$ & $=$ & $t-2<x-1$ & 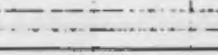 & $z$ & $=-1$ & \\
\hline$=$ & $\omega_{1}+2$ & $=-$ ot & +4 & $-7 v^{2}=$ & $\Rightarrow$ & & & $=$ & - & $=$ & $=$ & $=$ & & $\cdots$ & : & a) & $=$ & \\
\hline$=$ & $=$ & $\frac{-5}{2}=4$ & \pm & 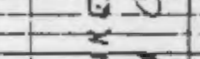 & $=-2$ & & & - & & 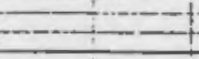 & & $\cdots$ & & $\ldots$ & & & $\cdots$ & \\
\hline 0 & $=$ & -3 & 80 & $-a+1$ & $=-7$ & - & & -1 & & $=-1$ & & {[} & & & $-x=\frac{c}{3}$ & $\theta$ & $\ldots+$ & \\
\hline $1--=$ & $-1-1$ & $7-2-13$ & 1 & $+-19-x-$ & $\Longrightarrow$ & - & $=$ & $=$ & & $-1-1$ & $=$ & $\cdots$ & & $\cdots$ & $\cdots \cdots=0$ & & - & \\
\hline$=\div$ & $E=$ & +1 & $\Rightarrow 2=$ & सं-cin & $\Rightarrow$ & 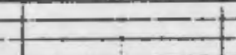 & $=$ & & 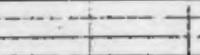 & + & $=$ & $0-1$ & & $\because$ & -4 & & $=$ & \\
\hline-1 & $=+t$ & $1-25$ & $=-1+3$ & $y-2,4$ & $=1$ & & & & & $E$ & & $=-1+u=$ & $\ldots$ & $\ldots \ldots$ & 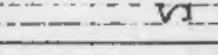 & & $-\ldots$ & \\
\hline$-\div$ & -7 & $\therefore-1$ & $-\frac{3}{3}-8$ & $=0$ & $=1$ & $\cdots$ & 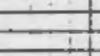 & $=$ & $=$ & $\underline{E}$ & & $=-1 ; \ldots$ & & $=$ & $\cdots$ & $=$ & 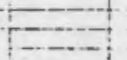 & \\
\hline$-\cdots$ & $=\frac{\mathrm{sa}}{\mathrm{at}}$ & $15 \pi$ & $3 \quad \frac{3}{3}$ & $=2<1$ & $-t$ & $\longrightarrow$ & - & {$[-$} & 一 & $-1 \ldots 1$ & $\longrightarrow$ & $-+-\ldots$ & & $-\cdots$ & $\cdots-\cdots$ & & -1 & \\
\hline$\cdots+$ & $1=-1$ & $1+3$ & 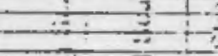 & $=$ & $\cdots$ & {$[-$} & $\rightarrow$ & & & 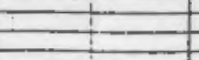 & & & & & $=$ & & $E$ & \\
\hline 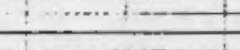 & $\ldots$ & +2 & $6-\frac{7}{2}+1$ & $-\frac{1}{3}-\frac{1}{3}$ & $=-1$ & & $=$ & $1=-1$ & & 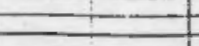 & & & & $\cdots$ & & & & \\
\hline- & $\ldots$ & $\frac{2}{3}-5$ & $-3: 5$ & $-\frac{2}{3}-\frac{2}{3}$ & $-\cdots$ & & & $-1+1$ & & & & $\ldots$ & & & & & $=$ & \\
\hline-5 & $\rightarrow$ & -1 & & & $=$ & $\cdots$ & $\cdots$ & 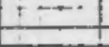 & ... & $z=-1 \cdots-1$ & & ....- & $A$ & & & & $=$ & \\
\hline$\Rightarrow$ & $E$ & $-1-$ & $-\square$ & 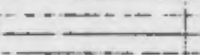 & in & $=-$ & $=$ & - & & $=-1$ & & - & $\sqrt{ }$ & Fot: & $=$ & & & \\
\hline$=$ & $=$ & 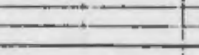 & $\Xi$ & $=$ & & & & & & 4 & & & & 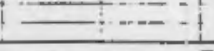 & & & & \\
\hline$\cdots$ & & -5 & & - & & & & & & & & & & & & & $E-$ & \\
\hline & & $-C_{1}$ & $-1-$ & $-1-1$ & $\div 二$ & & 7 & & & & & & $\cdots$ & & & $=-$ & $=$ & \\
\hline $0-1$ & -1 & $E+\cdots$ & $\cdots+1-$ & $\ldots \ldots \ldots$ & $\cdots$ & - & - & $-\cdots$ & 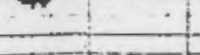 & -1. & $\cdots+1$ & $-\ldots$ & $=i . .$. & 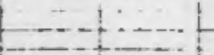 & $\therefore \cdots=1$ & & $\therefore-1$ & 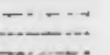 \\
\hline$-\ldots$ & $=-1$ & $-\cdots$ & $=$ & $=-1-1$ & $=-$ & 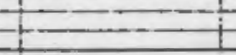 & 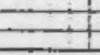 & $=$ & $\cdots$ & $--1+1$ & $=1-1$ & 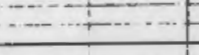 & $\ldots$ & $\ldots$ & - & $0+1$ & $=$ & 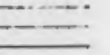 \\
\hline$-1=$ & $-\cdots$ & 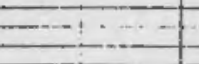 & $=1-1$ & $\because-1$ & $=i^{n}$ & $=-1+3$ & 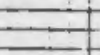 & $\Rightarrow f$ & $\ldots$ & $=1-1$ & 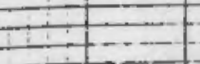 & 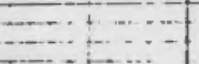 & 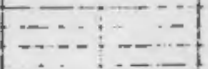 & $\because x+\cdots$ & $=\cdots$ & $=+x^{n}$ & $=1$ & 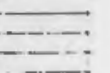 \\
\hline & & & & & -0 & & & & & & & $\cdots$ & & & & & & \\
\hline$-i-$ & -1 & & $\Longrightarrow$ & -1 & $=$ & 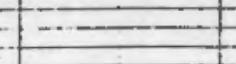 & 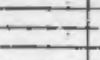 & $E$ & E. & - & & \begin{tabular}{l|l}
$\cdots$ \\
\hdashline
\end{tabular} & -1. & $-\cdots$ & $\ldots \ldots+$ & & & \\
\hline
\end{tabular}

Well 399-1-20 Natural Gamma Log, October 20, 1988 



PNL -6910

UC - 11,41

\section{DISTRIBUTION}

No. of

Copies

OFFSITE

2 DOE/Office of Scientific and Technical Information

\section{ONSITE}

2 DOE Richland Operations Office

E. A. Bracken

M. W. Tiernan

2 Westinghouse Hanford Company

K. R. Fecht

R. L. Jackson
No. of

Copies

25 Pacific Northwest Laboratory

S. P. Airhart

R. W. Bryce

J. W. Falco

M. D. Freshley

T. J. Gilmore

L. K. Grove

J. M. Hales

P. C. Hays

E. J. Jensen

G. V. Last

R. E. Lundgren

S. P. Luttre]1

P. J. Mitche 11

R. W. Nelson

R. Schalla

R. L. Skaggs

R. M. Smith

J. A. Stottlenyre

R. E. Wildung

Publishing Coordination

Technical Report Files (5) 
